TABLE

Comparison between consultant appointments in mental handicap between 1983 and 1986

\begin{tabular}{|c|c|c|c|c|c|c|c|c|c|}
\hline \multirow[t]{2}{*}{ Region } & \multirow[t]{2}{*}{ Population } & \multirow[t]{2}{*}{ Estab. } & \multirow[t]{2}{*}{ Vacant } & \multicolumn{2}{|c|}{ Population/Cons. } & \multirow[t]{2}{*}{ Estab. } & \multirow[t]{2}{*}{ Vacant } & \multicolumn{2}{|c|}{ Population/Cons. } \\
\hline & & & & Nominal & Substant. & & & Nominal & Substant. \\
\hline $\begin{array}{c}\text { South West } \\
\text { Thames }\end{array}$ & $2,906,000$ & 19 & 5 & 153,000 & 208,000 & 22 & 5 & 132,000 & 182,000 \\
\hline South Western & $3,029,000$ & 18 & 3 & 168,000 & 202,000 & 17.5 & 0 & 173,000 & 173,000 \\
\hline East Anglia & $1,863,000$ & 11 & 3 & 169,000 & 233,000 & 11 & 2 & 169,000 & 207,000 \\
\hline West Midland & $5,161,000$ & 17 & 6 & 304,000 & 469,000 & 21 & 1 & 245,000 & 258,000 \\
\hline Merseyside & $2,458,000$ & 8 & 2 & 307,000 & 410,000 & 10.5 & 1 & 234,000 & 259,000 \\
\hline Oxford & $2,340,000$ & 7 & 2 & 334,000 & 468,000 & 14 & 3 & 167,000 & 213,000 \\
\hline $\begin{array}{c}\text { North West } \\
\text { Thames }\end{array}$ & $3,460,000$ & 10 & $\mathbf{0}$ & 346,000 & 346,000 & 15 & 2 & 231,000 & 266,000 \\
\hline Trent & $4,517,000$ & 13 & 7 & 347,000 & 752,000 & 20 & 6 & 226,000 & 323,000 \\
\hline $\begin{array}{l}\text { North East } \\
\text { Thames }\end{array}$ & $3,772,000$ & 10 & 4 & 377,000 & 629,000 & 16 & 1 & 236,000 & 251,000 \\
\hline Northern & $3,087,000$ & 8 & 3 & 385,000 & 617,000 & 11 & 1 & 281,000 & 309,000 \\
\hline $\begin{array}{c}\text { South East } \\
\text { Thames }\end{array}$ & $3,544,000$ & 9 & 1 & 394,000 & 443,000 & 13 & 5 & 273,000 & 443,000 \\
\hline Wessex & $2,744,000$ & 6 & 3 & 457,000 & 915,000 & 6 & 0 & 457,000 & 457,000 \\
\hline Yorkshire & $3,577,000$ & 7 & 5 & 511,000 & 715,000 & 12.5 & 5 & 286,000 & 477,000 \\
\hline North West & $4,339,000$ & 7 & 5 & 620,000 & $2,170,000$ & 13.5 & 5 & 321,000 & 510,000 \\
\hline TOTALS & $46,797,000$ & 150 & 49 & 312,000 & 463,000 & 203 & 38 & 231,000 & 284,000 \\
\hline
\end{tabular}

\title{
The Role of the Consultant Psychiatrist in Mental Handicap
}

\section{A Personal View}

\author{
Caroline Marriott, Senior Registrar, Stradreagh Hospital, Londonderry, Northern Ireland
}

Since taking the decision to pursue a career in mental handicap, I have been increasingly aware of the debate surrounding the role of the consultant psychiatrist in this field. Nowhere else in medicine does there seem to be such uncertainty about the continued need for an already established specialty. I believe that one of the major reasons for the continued difficulty in attracting trainees into mental handicap is precisely this uncertainty about its future, which is in no way ameliorated by the College's view that a full time specialist appointment in the psychiatry of mental handicap is not superior to a joint appointment either with adult or child psychiatry. ${ }^{1}$

It seems clear that the case for the core involvement of the specialist consultant psychiatrist in the planning and provision of services for the mentally handicapped (in addition to providing a psychiatric service for them) has not been made. Are we opting out? I suspect that the Select Committee for Social Services believes we are, and it appears they believe we should not. ${ }^{2}$

I believe that there is a real need for full-time, properly trained specialists in mental handicap, and that their role should be a broadly based one, set in a holistic view of the needs of the mentally handicapped person and his family, and in encouraging mental health rather than treating psychiatric disorder after it has arisen.

The principles on which the role of the consultant psychiatrist in mental handicap should be based have been well stated by DHSS (NI) in $1978 .{ }^{3}$ Broadly, they are as follows:

(1) He should be concerned with the initial and on-going assessment of mental handicap, and the provision of a psychiatric service for affected individuals.

(2) He must be concerned with the prevention and assessment of emotional disturbance in the handicapped person and/or his family.

(3) He must give medical leadership within the hospital part of the service, and in the management and support of the handicapped and their families.

(4) He should act effectively in co-ordinated multidisciplinary teams which exist for the benefit of the handicapped for whose care he (in liaison with the general practitioner) has clinical responsibility. 
(5) He must take a full share in the management of all services for the mentally handicapped.

(6) He has an essential part to play in health care planning.

(7) He has an essential function in research and in teaching.

It follows from these principles that the consultant in mental handicap must work closely with all other medical and non-medical professionals likely to be in contact with mentally handicapped people. Good relationships with other professionals and the early involvement of a coordinated mental handicap team can only improve the quality of care provided. Equally, this will help to ameliorate the stigma and fear still unfortunately associated with the mental handicap 'label', thus lessening an all too frequent additional difficulty which families experience in coming to terms with the presence of a mentally handicapped member.

Early referral, via the consultant, to a specialist service will assist in the keeping of up-to-date demographic information on the needs of the mentally handicapped in any community (ideally with the use of a register as recommended by the Select Committee and perhaps following the Northern Ireland model) which is a prerequisite for the sensible planning of services. The consultant should also be in a position to ensure both that no one who could benefit from the services provided will miss out and that there is not duplication or conflict of advice and/or service offered.

The reality of community care policies is that mentally handicapped people and their families will be subjected to more stress, not less, so that the need for psychiatric specialist expertise in dealing with emotional disturbance, and neurotic disorders particularly, is likely to increase greatly. Clearly, given the nature of the fundamental handicap, specialist expertise must be brought to the diagnosis and management of psychiatric, emotional, behavioural and neurological disorders in mentally handicapped people.

The consultant, in fulfilling his role, must have strong links with the community based non-medical and residential facilities provided - perhaps most usefully by holding regular 'clinics' in workshops, adult training centres, hostels, schools, etc, rather than in hospitals. He should be readily accessible to parents and others involved in the care of the mentally handicapped so that when problems arise, they do not become worse because of a long administrative delay between a request for help and a consultation, or because of an inappropriately directed referral to another member of the team. Here the holistic nature of the medical and general psychiatric training he has undergone is essential for the proper co-ordination of a needs-based rather than a rigidly professionally bounded team service. Clearly, much of the consultant's time will be spent away from the hospital in the 'community', working to ensure the mental health of his patients rather than simply working to treat their mental illness.

The consultant should have clearly defined responsibility for ensuring that the total service 'package' for the mentally handicapped in his geographical area of work is the best that can be secured. In this regard, his clinical autonomy and specialist training should place him in the ideal position to advise those agencies responsible for planning and delivering the service. He should also foster good relationships with voluntary bodies concerned with the mentally handicapped, both in an advisory capacity and, where appropriate, providing professional backing in their attempts to improve the lot of mentally handicapped people.

It is clear that not all will wish to do 'pure' research. However, demographic and 'problem orientated' research is a necessary prerequisite for anyone advising on service provision, so that all consultants should have a responsibility to carry out at least this minimal research function. Equally, all should have a duty to teach about mental handicap - whether it be to other professionals or trainees likely to be involved in the care of the mentally handicapped, or more broadly to the wider community. The need for the myths surrounding mental handicap to be exploded is more and more urgent as we forge ahead with community care policies against a background of ill-prepared and therefore often frankly hostile communities.

Clearly, if one is to perform all of the above functions, a 'split' commitment with another specialty is inappropriate one or both specialties is bound to suffer. Equally, no psychiatrist could hope to fulfil this suggested role unless a further, fundamental principle is added - namely that his training must be such that his qualifications will be accepted and will stand up to close examination, whether from within or outside the profession.

Therefore, assuming a good and varied pre-Membership experience, specialist training must include exposure to the following in addition to the clinical experience necessary to develop the psychiatric skills required, i.e., assessment of intellectual handicap and psychological status, domiciliary, out-patient and in-patient care and rehabilitation: medical genetics; paediatric developmental assessment; neurology (with special reference to epilepsy, sensory handicap and cerebral palsy); assessment and management of orthopaedic problems in the mentally handicapped; psychotherapeutic work with families; forensic psychiatry with particular reference to mentally handicapped offenders; management planning and team leadership skills training; and community work geared to increased understanding of the role and expertise of clinical psychologists, physiotherapists, social workers, community nurses and other professionals working in the field of mental handicap.

I believe that individual psychiatrists could meet this challenge - will the College play its part by encouraging the development of this role and the necessary training to fulfil it?

\section{Reperences}

'Royal College of Psychiatrists (1983) Mental handicap services-the future. Bulletin of the Royal College of Psychiatrists, 7, 131-134.

${ }^{2}$ House of Commons Social Services Comartre (1978) Second Report - Community Care Recommendation 78.

${ }^{3}$ Department of Health and Social Securrty (NI) (1978) Services for the Mentally Handicapped in Northern IrelandPolicy and Objectives. 